Group

WeSt SNOWDON

SNOWDON

GLYDER

CarnedD
TABLE I (cont.)

\section{Name of Cum}

\begin{tabular}{|c|c|c|c|}
\hline & \multicolumn{2}{|c|}{ Altitude } & Aspect \\
\hline & Feet & Metres & \\
\hline$\cdots$ & 1200 & 365 & $\circ$ \\
\hline . & 1100 & 335 & 0 \\
\hline . & $\therefore \quad 1200$ & 365 & $\circ$ \\
\hline . & .. $\quad 1100$ & 335 & $\circ$ \\
\hline * & 1300 & 395 & 45 \\
\hline$\cdots$ & 900 & 275 & 45 \\
\hline - & I 500 & 455 & 45 \\
\hline . & $\ldots \quad 1700$ & 520 & $\circ$ \\
\hline$\cdots$ & .. 1700 & 520 & 320 \\
\hline . & .. 1600 & 490 & 140 \\
\hline$\cdots$ & . 2000 & 610 & 90 \\
\hline - & 1400 & 425 & 90 \\
\hline . & 1000 & 305 & 100 \\
\hline . & 1400 & 425 & 45 \\
\hline . & 900 & 275 & 45 \\
\hline * & .. 1600 & 490 & 50 \\
\hline . & 2000 & 610 & 350 \\
\hline . & 1240 & 380 & 40 \\
\hline & 1970 & 600 & $90-100$ \\
\hline & .. 1760 & 540 & $55-65$ \\
\hline & .. 1640 & 500 & $50-55$ \\
\hline . & .. 2050 & 625 & $70-75$ \\
\hline${ }^{\circ}$ & .. 2300 & 700 & 70 \\
\hline . & 1280 & 390 & I $5-20$ \\
\hline$\cdot$ & 1250 & 380 & $15-20$ \\
\hline & .. $\quad 1800$ & 550 & 0 \\
\hline$\circ$ & .. 1400 & 425 & 20 \\
\hline 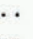 & 2200 & 670 & 120 \\
\hline . & 1800 & 550 & 180 \\
\hline . & 2100 & 640 & 350 \\
\hline - & 2400 & 730 & 45 \\
\hline & 2100 & 640 & 90 \\
\hline & 1800 & 550 & 90 \\
\hline & 1600 & 490 & 45 \\
\hline
\end{tabular}

\title{
ICE ACTION ON NEW ENGLAND LAKES
}

\author{
By Lawrence GoldthwatT
}

(Science Department, St. George's School, Newport, R.I., U.S.A.)

\begin{abstract}
Motion produced by ice expansion and by wind-blown ice cakes has modified the shores of lakes in northern New England, U.S.A. Twenty-six lakes have been studied, the processes observed, and measurements

Zusammenfassung. Die durch Ausdehnung von Eis und durch windgewehte Eiskuchen hervorgerufene Bewegung hat die Ufer von Seen in Nord-Neu-England, U.S.A., modifiziert. Sechsundzwanzig Seen wurden untersucht, die Prozesse beobachtet, und Messungen vom Verlauf und Ausmass der Eisaktion gemacht. Schlussfolgerungen
\end{abstract}

\section{INTRODUCTION}

The shores of many lakes are altered by the action of expanding ice cover and wind-blown ice cakes. As far back as 1822 Lee ${ }^{1}$ reported moving rocks in Connecticut. Later many articles have dealt with the origin of ice action features, notably articles by Buckley ${ }^{2}$ and by Gilbert ${ }^{3}$ on Wisconsin, by 'Tyrrell ${ }^{4}$ on northern Canada, and by Hellaakoski ${ }^{5}$ on Finland. Recently Stanley ${ }^{6}$ described the dragging of boulders in the Death Valley region in California by wind-blown ice 
cakes. Many questions remain unanswered as to the nature and rate of ice action. This paper records the results of field observations and experiments made on lakes in northern New England.

\section{OBSERVATIONS}

The 26 lakes studied are located in Maine, New Hampshire and Vermont and range in size from Rockybound Pond, roughly 0.8 by $0.32 \mathrm{~km}$. to Lake Winnepesaukee, which is over $29 \mathrm{~km}$. long. Normal maximum ice thickness is between 40 and $60 \mathrm{~cm}$. However, the range of effective ice action over the years is considerably greater than $60 \mathrm{~cm}$. because of the fluctuation of lake level often as much as I $\mathrm{m}$. Furthermore, many of these lakes have been artificially raised or lowered during the last two centuries.

As the ice moves ashore as a result of wind push or of expansion, it tends to catch the larger rocks and drag them ashore. These accumulate higher on the shore leaving the smaller ones lower, thus forming a sorted pavement of rocks. Such pavements are found in all but 7 of the 26 lakes studied, the 7 being the smallest. Minimum lake size for definite indications of ice action is approximately $\mathrm{I} \cdot 2$ by $0.4 \mathrm{~km}$.

Permanent dirt ramparts form where ice pushes against gently sloping glacial till or gravel. Rocks and dirt are heaped and buckled into a ridge commonly 0.5 to $1.5 \mathrm{~m}$. high parallel to the shore. Ramparts are common features of the lake shores and may be found on any shore regardless of the direction it faces. Some lakes, such as Little Lake Sunapee, New Hampshire, are nearly ringed with ramparts. Fig. I (p. 103) shows a cake of ice after being pushed ashore. The ice was loaded with debris, and the shove was great enough to buckle and crack a road pavement $2 \mathrm{~m}$. from the road edge. In this particular case, in the spring of 1949, the ice covered the lake, and expansion resulted from one warm-cold-warm temperature cycle completed within 48 hours. This and other comparable situations suggests that the most violent ice push is produced by the expansion process.

Ice moving along or onto the shore may either grasp by freezing or drag the larger rocks. Of the dozens of moved rocks studied over the last twenty years, there has been no indication of rolling. The rocks not only keep the same upright position, but the heaps of debris on the front side of the rocks indicates a plowing action that leaves a trail behind. Fig. 2 (p. 103) illustrates ice pushed up on edge (by expansion in this case) and retaining the sand and rocks grasped from the lake floor. This method of transportation of rocks has been observed repeatedly on the lakes of northern New England.

Generally the direction of the boulder trail is onshore or slightly diagonal to the shore. Fig. 3 (p. IOI) illustrates the directions taken by boulders shoved by the ice in Lake Wentworth, New Hampshire. The trails selected were made by rocks usually over a meter in one dimension and appreciably larger than the pavement around them. The fact that the motion is strongly onshore suggests expansion as the process causing the moving of these larger rocks. The pattern of trails certainly implies that there was not just one center of radial expansion but many centers, each operating as an independent unit. The frequent development of ice-buckled ridges dividing the ice cover of the lake into several units further suggests this. If the trails were formed by wind-blown cakes one would expect to find numerous trails nearly parallel to the shore, and they are not.

None of the trails observed were curved, many were straight, and some were zigzag trails. The zigzag trails suggest that either the centers of expansion change or that the effective wind direction shifts.

Some remarkably long trails have been produced on shallow shelving lake floors. One trail in Lake Wentworth measures a total of $32 \mathrm{~m}$., $20 \mathrm{~m}$. of which is straight, the rest zigzags within I 8 degrees of the straight portion. The granodiorite boulder making this long trail measured $4.5 \times 2.5 \times 2.1 \mathrm{~m}$. The largest trail-producing rock measured in these lakes is $5.8 \times 2.5 \times 2 \mathrm{~m}$. or approximately $29 \mathrm{~m} .{ }^{3}$. Its trail is $6.5 \mathrm{~m}$. long and about $65 \mathrm{~cm}$. deep. It is unlikely that wind-blown ice cakes would be able to move rocks of such size after they have been weakened and rotted by melting in the Spring. It probably was done by expansion of hard ice. 


\section{EXPERIMENTS}

Little Lake Sunapee, an oval lake about $2 \cdot 8 \times \mathrm{r} \mathrm{km}$., is nearly bisected by an esker. Water only a meter or less deep separates the end of the esker from the south shore, a distance of about $30 \mathrm{~m}$. On both the east and west sides of the end of the esker 5 rocks were placed on the sandy lake floor, spaced $\mathrm{I} \cdot 2 \mathrm{~m}$. apart on lines at roughly right angles to the shore. Each of the ro rocks was about $25 \mathrm{~cm}$. in diameter and within reach of winter ice. After one winter these rocks were carefully relocated.

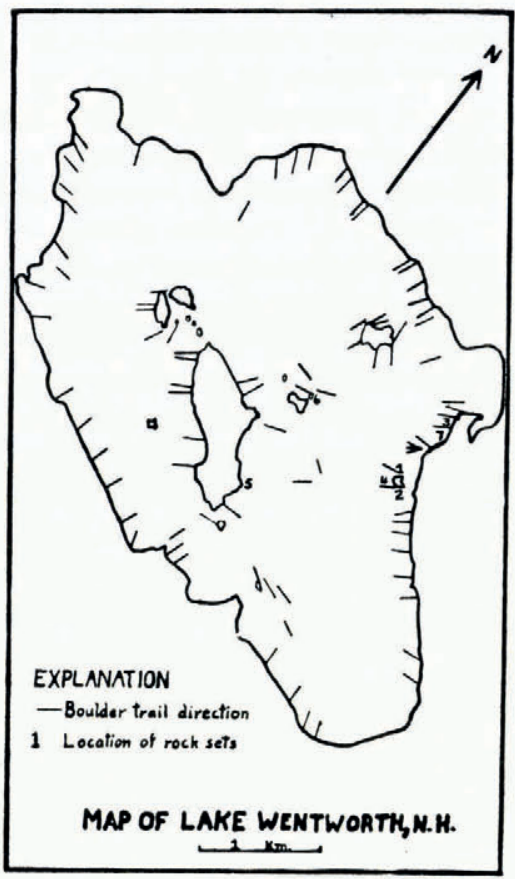

Fig. 3. Map of Lake Wentworth, New Hampshire. Straight lines indicate directions of rock trails. Numbers refer to locations of sets of rocks planted to indicate action of moving ice

All the rocks moved. With one exception they moved diagonally onto the point and along it (south) from both east and west sides. One rock moved along and outward slightly. The maximum motion was $36 \mathrm{~cm}$., the minimum $10 \mathrm{~cm}$. Ice action thus tends to extend the point southward and accounts for the accumulation of boulders in the form of a narrow rampart (see Fig. 4, p. 103) extending south from the esker to the shore.

In Lake Wentworth at locations, numbered I and 2 on Fig. 3, 8 boulders having trails were mapped annually over a period of 5 years. They ranged in size from $2.5 \times 1.5 \times 0.8 \mathrm{~m}$. to $100 \times 45$ $\times 22 \mathrm{~cm}$., and were at various depths of water. Over the 5 years there were 40 possible moves. Actually 18 moves took place. In 1949 all the rocks moved, while in 1952 only two did. The longest move was $146 \mathrm{~cm}$., the median move was $25 \mathrm{~cm}$. This was anusually active group of rocks since each year a number of the rocks would not have been reached by the ice at all because of the fluctuating lake level and of different depths in the water.

Each rock moved independently of the others in amount as well as in direction. Although the majority of moves were diagonally onshore 5 moved offshore as much as $23 \mathrm{~cm}$. The mechanism causing such motion is uncertain. Possibly as the ice chilled and shrank it would withdraw from the shore in places, but such motion has not been observed. A wind blowing along the shore at times causes cakes of ice to drag and rotate, possibly moving rocks out a limited amount. At the 
time of ice break-up, the cakes tend to pulsate back and forth as the water rises and falls in slow swells, moving small rocks outward by this mechanism. It is doubted however whether such action could move a rock $\mathrm{I} \cdot 5 \times \mathrm{I} \cdot 2 \times 0.6 \mathrm{~m}$. as much as $23 \mathrm{~cm}$. on a rocky floor.

Four sets of rocks were set out at locations numbered 3 and 6 on Fig. 3. Each of the sets consisted of 5 marked $23 \mathrm{~cm}$. boulders about equally spaced in shallow water to a depth of $1 \mathrm{~m}$. The locations of the rocks were mapped each year for 5 years.

Of the 20 rocks set out, 9 moved, and there were 13 moves greater than $7 \mathrm{~cm}$. The greatest number of moves in one year was 4 and the smallest 1 . Two reasons are suggested for the inactivity of many of the rocks. The depth range of the rocks was considerably greater than the normal ice thickness; as a result several of the rocks were either above or below the reach of the ice. Also the rocks used were nearly the size of the rocks already making up the pavements and therefore unlikely to be caught by the ice as it moved over the pavement.

At the location numbered 7 on Fig. 3 i rocks averaging $30 \mathrm{~cm}$. in diameter were mapped annually. They had a depth range of $1 \cdot 7 \mathrm{~m}$. and this shore was sandy with small cobbles. In 5 years all rocks moved with a total of 21 moves. The greatest displacement was $4.9 \mathrm{~m}$. with a median move of $3 \mathrm{I} \mathrm{cm}$. All motion was onshore. The high percentage and unusual length of moves suggests the importance of the large size of the rocks moved compared to the relatively fine texture of the pavement beneath.

Two rocks that were placed in shallow water on a sandy floor are illustrated in Fig. 5 (p. 103) (location 7 on Fig. 3). The broken mass of ice cakes extended offshore an estimated $40 \mathrm{~m}$. with open water beyond ard with a maximum fetch for waves of $4 \mathrm{~km}$. On the day when these rocks moved, having remained unmoved all winter, there was a strong onshore wind, somewhat variable in direction. Shoving by the wind-blown ice cakes was slow, pulsating and with considerable direction shift. Paths formed in the sand by the moving boulders were about $5 \mathrm{~cm}$. deep. One path was nearly straight for $1.8 \mathrm{~m}$. and the other was zigzag for a total of $4.9 \mathrm{~m}$. Shortly after motion ceased the ice cakes withdrew from shore about $8 \mathrm{~m}$. This was a ciear example of ice shove by wind-blown cakes producing a zigzag trail within a period of one hour.

\section{Conclusions}

Two processes involving ice action are effective in altering shores of lakes in northern New England. Contraction and expansion of ice due to temperature changes appear to be the dominant processes in moving the larger boulders. Wind-blown ice cakes produce the same kinds of changes on these lakes on a smaller scale. The rate at which boulders are moved, and therefore the time needed for the formation of sorted boulder pavements, certainly indicates that the lakes of northern New England have not been at their present levels for much of the time since glacierization and the formation of these lakes. The greatest motion occurs where boulders are appreciably larger than those surrounding and where the floor is smooth and gently sloping. The dominant direction of rock migration is diagonally or directly onshore with occasional motion offshore. The force of the moving ice is sufficient to plow granitic rocks as large as $29 \mathrm{~m} .{ }^{3}$ on a rocky floor.

MS. received 17 September 1956

\section{RE F EREN CES}

1. Lee, C. A. The moving rocks of Salisbury, Connecticut. American fournal of Science, Vol. 5, 1822, p. 34-7.

2. Buckley, E. R. Ice ramparts. Transactions of the Wisconsin Academy of Sciences, Vol. 13, Pt. 1, 1900, p. 14 1-62.

3. Gilbert, G. K. Lake ramparts. Sierra Club Bulletin, No. 6, 1908, p. 225-34.

4. Tyrrell, J. B. Ice on Canadian lakes. Transactions of the Canadian Institute, Vol. 9, 1909, p. I $3-21$.

5. Hellaakoski, A. Ice push on Lietvese, Lake Saimaa, during the winter of 1932. Fennia, 57, No. 3, 1932, p. 17-19. 6. Stanley, G. W. Origin of Playa stone tracks, Racetrack Playa, Inyo County, California. Bulletin of the Geological
Society of America, Vol. 66, No. 11 , 1955 , p. $1329-50$. 
